\title{
PARTISIPASI MASYARAKAT DALAM PENYUSUNAN RENCANA PEMBANGUNAN JANGKA MENENGAH DESA DI DESA SANGEH KECAMATAN ABIANSEMAL KABUPATEN BADUNG
}

\author{
Oleh: \\ I Ketut Suarjaya \\ Kantor Perbekel Sangeh \\ Email: kt.suarjaya@gmail.com
}

\begin{abstract}
Dartisipasi merupakan keterlibatan mental dan emosi dari seseorang di dalam situasi kelompok yang mendorong mereka untuk menyokong kepada kelompoknya. pencapaian tujuan kelompok tersebut dan ikut bertanggungjawab terhadap

Penelitian ini menggunakan pendekatan deskriptif kualitatif. Teori yang digunakan dalam penelitian ini adalah Teori Partisipasi Masyarakat menurut Holil (1980:8) yang menguraikan 5 indikator partisipasi masyarakat yaitu usia, jenis kelamin, pendidikan, pekerjaan dan pengahasilan serta lamanya tinggal.

Hasil penelitian menunjukkan bahwa partisipasi masyarakat dalam penyusunan RPJM Desa di Desa Sangeh Kecamatan Abiansemal Kabupaten Badung adalah partisipasi interaktif dan telah efektif tetapi terdapat beberapa kendala dalam pelaksanaanya. Berdasarkan hasil analisis dengan Teori Holil menunjukkan bahwa keaktifan masyarakat dalam berpartisipasi. Masyarakat perempuan memiliki kesempatan yang lebih sedikit dibandingkan masyarakat laki-laki untuk berpartisipasi dalam musyawarah penyusunan RPJM Desa. Masyarakat dengan tingkat pendidikan terakhir SMA memiliki tingkat keaktifan lebih tinggi dari masyarakat dengan tingkat pendidikan terakhir SD. Pekerjaan dan penghasilan yang dimiliki masyarakat Desa Sangeh tidak menghalangi kesadaran. masyarakat untuk berpartisipasi dalam penyusunan RPJM Desa. Semakin lama seseorang tinggal di Desa Sangeh maka rasa memiliki terhadap lingkungan cenderung lebih meningkatkan partisipasi dalam setiap kegiatan pembangunan ataupun penyusunan RPJM Desa. Faktor pendukung partisipasi masyarakat dalam penyusunan RPJM yaitu adanya sejarah komunitas Desa Sangeh, kepemimpinan dari pemimpin yang menjadi panutan masyarakat, kapasitas organisasi kemasyarakatan yang cukup dan sumber daya manusia yang memadai sedangkan faktor penghambat yaitu kurangnya pemahaman informasi program karena kurangnya pendekatan pemerintah dengan masyarakat dan adanya pelaksanaan program yang lama (melanjutkan proses program yang lama yang belum tuntas).
\end{abstract}

Kata Kunci: Partisipasi, RPJM

\section{Darticipation is the mental and emotional involvement of a person in a group situation that encourages them to support the achievement of the group's goals and take responsibility for the group.}

This research use desciptive qualitative approach. The theory used in this study is the Theory of Community Participation according to Holil (1980: 8) which outlines 5 indicators of community participation namely age, sex, education, employment and income and length of stay

The results showed that community participation in the preparation of the Village RPJM in Sangeh Village, Abiansemal District, Badung Regency was interactive and effective participation, but there were several obstacles in its implementation. Based on the results of the analysis with Holil Theory shows that the community's active participation. The women's community has fewer opportunities than the men's community to participate in the village medium term development planning deliberations. Communities with the highest level of education have a higher level of activity than those with the highest level of education. The work and income of the people of Sangeh Village do not hamper awareness. community to participate in the preparation of the Village RPJM. The longer a person stays in Sangeh Village, the sense of belonging to the environment tends to increase participation in every development activity or the preparation of the Village RPJM. Supporting factors for community participation in the preparation of the RPJM are the history of the Sangeh Village community, the leadership of leaders who are role models of the community, adequate community organizational capacity and adequate human resources while the inhibiting factor is the lack of understanding of program information due to the lack of government and community approaches and the implementation the old program (continue the old program process that has not been completed).

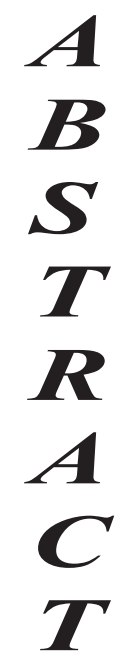




\section{A. PENDAHULUAN}

Partisipasi masyarakat merupakan keterlibatan anggota masyarakat dalam pembangunan dan pelaksanaan program atau proyek pembangunan yang dilakukan dalam masyarakat lokal. Partisipasi masyarakat memiliki ciri-ciri bersifat proaktif dan bahkan reaktif (artinya masyarakat ikut menalar baru bertindak), ada kesepakatan yang dilakukan oleh semua yang terlibat, ada tindakan yang mengisi kesepakatan tersebut, ada pembagian kewenangan dan tanggung jawab dalam kedudukan yang setara. Berdasarkan Undang Undang Nomor 6 Tahun 2014 tentang Desa mengamanatkan penyusunan Rencana Pembangunan Jangka Menengah Desa (RPJM Desa) dan Rencana Pembangunan Tahunan Desa atau yang disebut Rencana Kerja Pemerintah Desa (RKP Desa) kepada pemerintah desa. RPJM Desa adalah rencana kegiatan pembanguanan desa untuk jangka waktu 6 (enam) tahun dan RKP Desa sebagai penjabaran dari RPJM Desa berlaku dalam jangka waktu 1 (satu) tahun. RPJM Desa dan RKP Desa merupakan dasar dalam pembangunan desa dengan tujuan melakukan upaya peningkatan kualitas hidup dan kehidupan untuk sebesar-besarnya kesejahteraan masyarakat desa.

Seperti halnya Desa Sangeh Kecamatan Abiansemal Kabupaten Badung telah melaksanakan penyusunan dan penetapan Rencana Pembangunan Jangka Menengah Desa di Desa Sangeh telah memberikan dinamika pada pembangunan wilayah, baik pada ruang domestik masyarakat maupun pada ruang publik. Pembangunan tersebut dirasakan telah berdampak pada infrastruktur, ruang publik maupun pada perubahan ruang domestik masyarakat wilayah di Desa Sangeh Kecamatan Abiansemal Kabupaten Badung. RPJM Desa Sangeh tertuang dalam Peraturan Desa Sangeh No 6 Tahun 2014 tentang Rencana Pembangunan Jangka Menengah Desa (RPJMDesa) Tahun 2014-2019.

Salah satu perubahan yang dapat kita lihat secara langsung terkait dinamika pembangunan di Desa Sangeh Kecamatan Abiansemal Kabupaten Badung adalah adanya pembukaan jalan baru di Jalan Mulukbabi, pembukaan jalan baru ini menimbulkan alih fungsi lahan serta memberikan dampak yang baik dalam hal transportasi. Selain itu pembangunan desa juga terlihat dari kegiatan operasional posyandu lansia yang rutin dilaksanakan untuk meningkatkan kesejahteran dan kesehatan lansia. Selain itu terdapat fenomena lain yang dialami saat pelaksanaan musrenbang yaitu adanya usulan program yang diajukan tidak didasari oleh kajian yang disusun oleh teknisi karena masih kurangnya tenaga teknisi di masyarakat, usulan/ program yang diajukan tidak disertai dengan rencana kerja anggaran sehingga terkendala dalam penyusunan anggaran belanja desa. Dalam perencanaan anggaran sering terjadi ketimpangan serta keterlambatan pemutusan apakah program/usulan tersebut dianggarkan di Desa atau di Kabupaten, hal ini untuk menghindari pengganggaran ganda. 
Fenomena ini menjadi sebuah hal yang menarik untuk diulas, dalam perencanaan partisipatuf penyusunan Rencana Pembangunan Jangka Menengah Desa (RPJM Desa) dirasakan belum efektif dalam pelaksanaannya. Hal ini dibuktikan dengan dtemukan beberapa permasalahan yaitu :

a). Dalam pengajuan gagasan pembangunan di tingkat dusun hanya beberapa masyakarat tertentu yang aktif dalam pengajuan usulan pembangunan, misalnya masyarakat yang dituakan yang dianggap mampu mengajukan usulan tanpa mempertimbangkan kajian tertentu dalam pengajuan usulan.

b). Kurangnya keterlibatan gender dalam pelaksanaan Musyawarah Pembangunan Desa (Musrenbang Desa) yang dapat dilihat pada saat pelaksanaan musrenbang desa, kelompok wanita hanya diwakilkan oleh kelompok Pemberdayaan dan Kesejahteraan Keluarga atau hanya satu kader PKK dari masing-masing dusun.

c). Penentuan prioritas dalam musrenbang desa belum mampu mengakomodir semua kepentingan masyarakat karena musyawarah hanya diwakilkan oleh beberapa tokoh masyarakat.

Berdasarkan uraian di atas, maka dalam penelitian ini peneliti mengkaji mengenai "Partisipasi Masyarakat Dalam Penyusunan Rencana Pembangunan Jangka Menengah Desa di Desa Sangeh Kecamatan Abiansemal Kabupaten Badung”.

\section{B. METODE}

Pendekatan penelitian yang digunakan dalam penelitian ini adalah penelitian deskriptif. Menurut Sugiyono (2017:11), "Penelitian deskriptif adalah penelitian yang dilakukan untuk mengetahui nilai baik satu variabel atau lebih (independent) tanpa membuat pembandingan atau hubungan dengan variabel lain”. Penelitian ini dilaksanakan pada Desa Sangeh Kecamatan Abiansemal Kabupaten Badung yang beralamat Desa Sangeh Kecamatan Abiansemal Kabupaten Badung, Bali sebagai tempat penelitian karena Desa Sangeh merupakan salah satu desa yang berada di Kabupaten Badung yang melakukan penyusunan RPJM Desa dalam upaya mewujudkan pembangunan Desa Sangeh.

\section{C.HASIL DAN PEMBAHASAN}

Partisipasi masyarakat adalah keikutsertaan masyarakat dalam proses pengidentifikasian masalah dan potensi yang ada di masyarakat, pemilihan dan pengambilan keputusan tentang alternatif solusi untuk menangani masalah, pelaksanaan upaya mengatasi masalah, dan keterlibatan masyarakat dalam proses mengevaluasi perubahan yang terjadi (Isbandi,2007:27). Adapun faktor yang mempengaruhi partisipasi masyarakat tersebut dijabarkan sebagai berikut: 
Faktor usia merupakan faktor yang mempengaruhi sikap seseorang terhadap kegiatankegiatan kemasyarakatan yang ada. Mereka dari kelompok usia menengah ke atas dengan keterikatan moral kepada nilai dan norma masyarakat yang lebih mantap,cenderung lebih banyak yang berpartisipasi daripada mereka yang dari kelompok usia lainnya. Partisipasi masyarakat ditinjau dari tingkat usia yaitu memberikan kesempatan kepada semua masyarakat yang berada dalam tingkatan remaja tergabung dalam sekaa truna dan dewasa yaitu masyarakat Desa Sangeh Kecamatan Abiansemal Kabupaten Badung. Tetapi dalam pelaksanaannya hanya beberapa masyarakat tertentu yang aktif dalam pengajuan usulan pembangunan, misalnya masyarakat yang dituakan yang dianggap mampu mengajukan usulan tanpa mempertimbangkan kajian tertentu dalam pengajuan usulan.

Ditinjau dari tingkat usia, adanya tokoh-tokoh masyarakat yang lebih dituakan memiliki partisipasi aktif dalam pemberian usulan program dengan asumsi tokoh masyarakat tersebut lebih berpengalaman dan memiliki wawasan mengenai program pembangunan. Maka dari itu, dibutuhkan adanya upaya dari perangkat desa untuk meningkatkan kesadaran masyarakat dan memberikan kesempatan kepada generasi milineal untuk menyampaikan pendapat dan menjadi pertimbangan dalam penyusunan RPJM Desa. Pembangunan membutuhkan perubahan dan tidak monoton pada satu tujuan dan kegiatan maka dari itu partisipasi masyarakat dari golongan milineal harus diperhatikan.

\section{b). Jenis kelamin}

Jenis kelamin ini yaitu perbedaan yang timbul karena memperhatikan gender yaitu laki-laki dan perempuan. Penyampaian gagasan dalam musyawarah pembangunan desa mengikutsertakan masyarakat perempuan yang tergabung dalam Pemberdayaan dan Kesejahteraan Keluarga (PKK). Partisipasi masyarakat ditinjau dari jenis kelamin menunjukkan bahwa dalam musyawarah penyusunan rencana pembangunan jangka menengah desa di Desa Sangeh Kecamatan Abiansemal Kabupaten Badung telah melibatkan masyarakat perempuan yang diwakilkan dalam kelompok PKK yaitu beberapa anggota PKK dan ketua PKK.

Maka dari itu pemerintah desa berupaya memberikan peningkatan proporsi untuk masyarakat perempuan dalam penyampaian usulan program. Penyetaraan gender ini sangat diperlukan untuk menghindari timbulnya kesenjangan sosial dalam masyarakat dalam penyampaian pendapat untuk penyusunan RPJM Desa.

\section{c). Pendidikan}


Pendidikan dianggap dapat mempengaruhi sikap hidup seseorang terhadap lingkungannya, suatu sikap yang diperlukan bagi peningkatan kesejahteraan seluruh masyarakat. Dalam penyampaian usulan, gagasan, masukan, ide ataupun saran tentu dilatarbelakangi atas tingkat pendidikan yang dimiliki oleh masyarakat tersebut. Partisipasi masyarakat ditinjau dari jenis kelamin menunjukkan bahwa masyarakat dengan tingkat pendidikan terakhir SMA memiliki tingkat keaktifan lebih tinggi dari masyarakat dengan tingkat pendidikan terakhir SD.

Hal ini menunjukkan bahwa semakin tinggi latar belakang pendidikan masyarakat maka akan semakin tinggi keaktifan masyarakatdalam berpartisipasi dalam musyawarah penyusunan rencana pembangunan jangka menengah desa di Desa Sangeh.Kondisi ini menunjukkan bahwa tingkat pengetahuan masyarakat berpengaruh terhadap usaha-usaha partisipasi yang diberikan masyarakat dalam pembangunan dan salah satu faktor yang mempengaruhi tingkat pengetahuan adalah tingkat pendidikan.

\section{d). Pekerjaan dan penghasilan}

Pekerjaan dan penghasilan yang baik dan mencukupi kebutuhan sehari-hari dapat mendorong seseorang untuk berpartisipasi dalam kegiatan-kegiatan masyarakat. Pengertiannya bahwa untuk berpartisipasi dalam suatu kegiatan, harus didukung oleh perekonomian yang mapan. Partisipasi masyarakat ditinjau dari pekerjaan dan penghasilan menunjukkan bahwa semua masyarakat Desa Sangeh kompak dalam menghadiri pertemuan desa tanpa mempertimbangkan pekerjaan ataupun penghasilan yang tinggi ataupun rendah demi kemajuan desa.Kondisi ini menunjukkan bahwa pekerjaan dan penghasilan yang dimiliki masyarakat Desa Sangeh tidak menghalangi kesadaran masyarakat untuk berpartisipasi dalam penyusunan RPJM Desa.

\section{e). Lamanya tinggal}

Lamanya seseorang tinggal dalam lingkungan tertentu dan pengalamannya berinteraksi dengan lingkungan tersebut akan berpengaruh pada partisipasi seseorang. Semakin lama ia tinggal dalam lingkungan tertentu, maka rasa memiliki terhadap lingkungan cenderung lebih terlihat dalam partisipasinya yang besar dalam setiap kegiatan lingkungan tersebut. Partisipasi masyarakat ditinjau dari lamanya tinggal menunjukkan bahwa lamanya tinggal seseorang atau masyarakat dalam lingkungan tertentu dan pengalamannya berinteraksi dengan lingkungan tersebut dapat mempengaruhi partisipasi seseorang atau masyarakat. Hal ini menunjukkan bahwa semakin lama seseorang tinggal di Desa Sangeh, Kecamatan Abiansemal, Kabupaten Badung maka rasa memiliki terhadap lingkungan cenderung lebih meningkatkan partisipasi dalam setiap kegiatan pembangunan ataupun penyusunan RPJM Desa. 
Dalam pelaksanaan partisipasi masyarakat dalam penyusunan Rencana Pembangunan Jangka Menengah Desa di Desa Sangeh Kecamatan Abiansemal Kabupaten Badung terdapat beberapa faktor-faktor yang mempengaruh partisipasi masyarakat yang terdiri dari faktor pendukung dan penghambat. Adapun faktor tersebut yaitu :

\section{a. Faktor Pendukung}

\section{- Sejarah Komunitas}

Desa Sangeh memiliki sejarah komunitas yang kuat dan mampu menjadi semangat dan motivasi bagi masyarakat dalam berpartisipasi. Sejarah komunitas Desa Sangeh, Kecamatan Abiansemal, Kabupaten Badung yaitu faktor yang mendorong partisipasi masyarakat serta mampu meningkatkan kesadaran masyarakat untuk berpartisipasi.

\section{- Kepemimpinan}

Keberhasilan partisipasi masyarakat Desa Sangeh Kecamatan Abiansemal Kabupaten Badung dapat dilihat dari adanya kepemimpinan yang baik dari pemimpin atau tokoh-tokoh masyarakat sehingga dapat dijadikan panutan dalam masyarakat. Kepemimpinan yang baik mampu meningkatkan kesadaran masyarakat untuk berpartisipasi. Serta didukung dari peran tokoh masyarakat Desa Sangeh Kecamatan Abiansemal Kabupaten Badung dalam mengayomi dan memimpin masyarakat dengan mengutamakan kepentingan umum di atas kepentingan pribadi. Maka dari itu akan ada yang dapat dijadikan panutan oleh masyarakat untuk terlibat secara maksimal dalam pelaksanaan program.

\section{- Organisasi Kemasyarakatan}

Organisasi kemasyarakatan merupakan salah satu wadah yang menghimpun tokoh-tokoh masyarakat dan memiliki program kerja untuk mendorong terlaksananya pembangunan. Organisasi kemasyarakatan di Desa Sangeh, Kecamatan Abiansemal, Kabupaten Badung memiliki kapasitas yang cukup terhadap pencapaian tujuan program pembangunan di Desa Sangeh.

\section{- Sumber Daya}

Sumber daya adalah faktor-faktor yang mendukung partisipasi masyarakat seperti sumber daya manusia yang dilihat dari sumber daya perangkat desa sebagai pelaksana dalam penyusunan RPJM Desa di Desa Sangeh, Kecamatan Abiansemal, Kabupaten Badung. Partispasi aktif masyarakat akan dapat tumbuh jika diiringi dengan sumber daya manusia yang memadai karena pada umumnya orang-orang yang memiliki sumber daya yang memadai saja yang banyak aktif dalam pelaksanaan kegiatan, sementara yang memiliki sumber daya yang terbatas (ekonomi lemah) sibuk dengan urusannya untuk mencari nafkah dan tidak mampu memberikan sumbangan 
pemikiran yang cukup berarti bagi pengembangan pelaksanaan program (pendidikan rendah).

\section{b. Faktor Penghambat}

\section{a). Pemahaman Informasi Program}

Adanya pendekatan-pendekatan yang dilakukan oleh pemerintah seharusnya dilakukan secara intensif sehingga mampu memberikan pemahaman bagi masyarakat mengenai program pembangunan yang disusun dalam RPJM Desa. Desa Sangeh masih terkendala dengan pemahaman informasi program yang disebabkan kurangnya pendekatan dari pemerintah dan tokoh masyarakat terhadap beberpa masyarakat yang lebih mampu sehingga tidak memahami dengan program pembangunan desa.

\section{b). Proses Pelaksanaan Program Yang Lama}

Pelaksanaan program yang lama yang belum selesai atau masih dalam proses serta program yang belum terlaksana dan dilaksanakan saat ini. Hal ini tentu menambah program yang harus dilaksanakan. Desa Sangeh masih terkendala dalam pelaksanaan program lama yang belum selesai atau terdapat program lama yang harus dilaksanakan saat ini. Hal ini menyebabkan penurunan partisipasi masyarakat dalam penyusunan RPJM Desa.

\section{D.SIMPULAN}

Berdasarkan uraian pembahasan hasil penelitian mengenai partisipasi masyarakat dalam penyusunan rencana pembangunan jangka menengah desa di Desa Sangeh Kecamatan Abiansemal Kabupaten Badung dapat disimpulkan :

a. Partisipasi masyarakat dalam penyusunan Rencana Pembangunan Jangka Menengah Desa di Desa Sangeh Kecamatan Abiansemal Kabupaten Badung adalah partisipasi interaktif dan telah efektif tetapi terdapat beberapa kendala dalam pelaksanaanya. Berdasarkan hasil analisis dengan menggunakan Teori Partisipasi Masyarakat menurut Holil (1980:8) menunjukkan bahwa tingkat usia menentukan keaktifan masyarakat dalam berpartisipasi. Adanya tokoh-tokoh masyarakat yang lebih dituakan memiliki partisipasi lebih aktif dibandingkan masyarakat yang lebih muda. Ditinjau dari jenis kelamin menunjukkan bahwa masyarakat perempuan memiliki kesempatan yang lebih sedikit dibandingkan masyarakat laki-laki untuk berpartisipasi dalam musyawarah penyusunan RPJM Desa. Ditinjau dari tingkat pendidikan menunjukkan masyarakat dengan tingkat pendidikan terakhir SMA memiliki tingkat keaktifan lebih tinggi dari masyarakat dengan tingkat pendidikan terakhir SD. Ditinjau dari pekerjaan dan penghasilan yang dimiliki masyarakat Desa Sangeh tidak menghalangi kesadaran masyarakat untuk berpartisipasi dalam penyusunan RPJM Desa. Ditinjau dari lamanya tinggal menunjukkan bahwa semakin lama seseorang tinggal di Desa Sangeh, 
Kecamatan Abiansemal maka rasa memiliki terhadap lingkungan cenderung lebih meningkatkan partisipasi dalam setiap kegiatan pembangunan ataupun penyusunan RPJM Desa.

b. Faktor pendukung dan faktor penghambat partisipasi masyarakat dalam penyusunan Rencana Pembangunan Jangka Menengah Desa di Desa Sangeh Kecamatan Abiansemal Kabupaten Badung yaitu :

a). Faktor pendukung

- Adanya sejarah komunitas Desa Sangeh

- Kepemimpinan dari pemimpin yang menjadi panutan masyarakat

- Kapasitas organisasi kemasyarakatan yang cukup

- Sumber daya manusia yang memadai

b). Faktor Penghambat

- Kurangnya pemahaman informasi program karena kurangnya pendekatan pemerintah dengan masyarakat

- Adanya pelaksanaan program yang lama (melanjutkan proses program yang lama yang belum tuntas).

\section{E. DAFTAR PUSTAKA}

Holil, Soelaiman. 1980. Partisipasi Sosial Dalam Usaha Kesejahteraan Sosial. Bandung : Badan Penelitian dan Pengembangan Sosial.

Isbandi, RA. 2007. Interview Komunitas Pengembangan Masyarakat Sebagai Upaya Pemberdayaan Masyarakat. Jakarta :PT Raja Grafindo Persada.

Peraturan Desa Sangeh No 6 Tahun 2014 tentang Rencana Pembangunan Jangka Mnengah Desa (RPJM-Desa) Tahun 2014-2019

Sugiyono, 2008. Metode Penelitan Kuantitatif dan Kualitatif. Bandung: Alfabeta 2017. Metode Penelitan Kuantitatif, Kualitatif dan R \& B. Bandung: Alfabeta 